Research Article

\title{
Chromium Laden Soil, Water, and Vegetables nearby Tanning Industries: Speciation and Spatial Distribution
}

\author{
Adugnaw Maru Gezahegn, Fekadu Fufa Feyessa, Esayas Alemayehu Tekeste, \\ and Embialle Mengistie Beyene \\ Department of Civil and Environmental Engineering, Jimma Institute of Technology, Jimma University, Jimma, Ethiopia \\ Correspondence should be addressed to Embialle Mengistie Beyene; embiale.mengiste@ju.edu.et
}

Received 10 January 2021; Accepted 15 June 2021; Published 23 June 2021

Academic Editor: Dario Pasini

Copyright (C) 2021 Adugnaw Maru Gezahegn et al. This is an open access article distributed under the Creative Commons Attribution License, which permits unrestricted use, distribution, and reproduction in any medium, provided the original work is properly cited.

\begin{abstract}
This study investigates the spatial distribution and speciation of chromium in water, soil, and edible plants in tannery-contaminated areas at Modjo city, Ethiopia. Modjo city is one of the industrial zones in the country, which is dominated by tanneries due to the ease of effluent discharge and water use from the nearby Modjo River crossing the city. The river, which received chromium-containing effluent from the tanneries, is also used for urban gardening of edible plants besides other domestic purposes. 12 water and 12 soil samples from contaminated areas and 6 samples from different edible plants grown nearby tanneries were collected following the standard procedure to predict the level of chromium contamination in the environment and its health risk. The total chromium in Modjo River was $20.6 \mathrm{mg} \mathrm{L}^{-1}$ in the upstream region which later was significantly reduced $(r=-0.93, p<0.05)$ to $0.126 \mathrm{mg} \mathrm{L}^{-1}$ in the very downstream region. However, the $\mathrm{Cr}(\mathrm{VI})$ concentration ranges from $0.23 \pm 0.032$ to $2.82 \pm 0.02 \mathrm{mg} \mathrm{L}^{-1}$ with a statistically insignificant decrease $(r=-0.76, p>0.05)$ to the downstream sampling points. The lowest $\mathrm{Cr}$ (III) and Cr (VI) concentrations in the soil were $2.78 \pm 0.37$ and $4.57 \pm 1.01 \mathrm{mg} \mathrm{kg}^{-1}$, respectively, which are higher $(p<0.05)$ than the control and the guideline values. Similarly, the chromium concentration in the edible plants was also $7.98 \pm 0.63 \mathrm{mg} \mathrm{kg}^{-1}$ for green pepper to $14.45 \pm 0.34 \mathrm{mg} \mathrm{kg}^{-1}$ for carrot with a trend of carrot $>$ beetroot $>$ lettuce $>$ cabbage $>$ tomato $>$ green pepper. The chromium in the plants from the contaminated area was significantly higher $(p<0.05)$ than the control area, which is between $0.14 \mathrm{mg} \mathrm{kg}^{-1}$ for lettuce and $0.31 \pm 0.01 \mathrm{mg} \mathrm{kg}^{-1}$ for tomato. It is also confirmed that the root part of plants accumulates more chromium than the leaf and the fruits. It is concluded that water and soil in tannery surroundings and edible plants grown in the area contain chromium concentrations higher than the recommended amount for a healthy environment and human consumption. Therefore, appropriate wastewater treatment, stringent regulations, and public awareness are recommended to reduce chromium contamination and its impact on public health and the environment.
\end{abstract}

\section{Introduction}

Chromium is one of the most abundantly found trace elements that exhibit several oxidation states, ranging from 0 to +6 , which dictates its chemical reactivity and environmental and biological importance $[1,2]$. However, trivalent $(\mathrm{Cr}$ (III)) and hexavalent (Cr (VI)) chromium are the two common oxidation states found in the aquatic environment [3]. Due to its strong tendency to form kinetically inert hexacoordinate with water and other chemicals, Cr (III) is the most stable and common form of this element $[4,5]$. Cr (VI), on the other hand, is highly mobile in the environment and easily migrate into the cell of living organisms that make it directly toxic to the living cell and have carcinogenic and mutagenic effects $[6,7]$. On the contrary, Cr (III) has essential nutritional benefits for plants and several health benefits to humans and animals [3]. The maximum allowable concentration of $\mathrm{Cr}(\mathrm{VI})$ in drinking above which poses serious health problems is $0.05 \mathrm{mg} \mathrm{L}^{-1}$. In higher exposure, higher than $0.1 \mathrm{mg} \mathrm{g}^{-1}$ of body weight, $\mathrm{Cr}$ (VI) can even be lethal $[7,8]$.

Chromium is one of the known environmental contaminants that enter the soil, water, and air from various natural and anthropogenic sources [9]. Tanneries, 
electroplating, and glass manufacturing industries, wood preservatives, old textile dyeing, pigment manufacturing, and organic synthesis are some of the major sources of chromium in the environment $[10,11]$.

The leather industry is an important contributor to the global economy, which aims at converting putrescible and unattractive animals' skin into nonputrescible, manageable, and attractive leather through a process called tanning [4]. The main tanning agent used by $90 \%$ of the world's tanneries is chromium-bearing chemicals, among which basic chromium sulfate $\left(\mathrm{Cr}(\mathrm{OH}) \mathrm{SO}_{4}\right)$ is the most popular one $[12,13]$. However, due to diffusion problems, the chromium salts used in the tanning process cannot be completely utilized by hiding tissues, and the excess will be discharged into the effluents thereby polluting the environment. In conventional tanning, the chromium uptake into the collagen of the skin is only $60-70 \%$ of the administered chromium while the rest more than $30 \%$ ends in the waste stream containing $1500-3000 \mathrm{mg} \mathrm{L}^{-1}$ chromium $[5,12,14]$.

The relative stability of $\mathrm{Cr}$ (III) in the environment and its nutritional benefit sometimes deceive to assume that the presence of this chromium form in the environment is not a critical problem. However, the recent detection and availability of Cr (VI) in industries (and their surrounding) which entirely use $\mathrm{Cr}$ (III) alarm the possible conversion of $\mathrm{Cr}$ (III) to toxic $\mathrm{Cr}$ (VI) in the environment and vice versa. It is documented that, during its movement through water and soil media, the possible oxidation and reduction of one form of chromium to the other are expedited by the presence of potential precursors such as ultraviolet radiation, manganese oxide, unsaturated fats, oxygen, moisture, certain enzymes, high temperature, and extreme $\mathrm{pH}[15,16]$.

Soil and water in the surrounding and discharge area of tanneries are often contaminated with chromium originated from partially treated or untreated effluent, chromiumcontaminated sludge and, leather trimming, and shaving $[5,14]$. Due to the ease of free available water, land, and nutrients mainly from organic pollutants in the wastewater, the cultivation of edible vegetables on riversides near tanneries discharge area is becoming common in towns of developing countries [17].

Ethiopia, with about 53.4 million cattle, 5.5 million sheep, and 22.7 million goats, is one of the richly endowed African countries in terms of livestock resources, which are ready sources of raw materials for the tanning industry. There are 32 tanning industries, more than 55 large leather goods and garment-manufacturing industries, and 22 large and mechanized shoe industries in Ethiopia. It is clear that the country has considerable potential in the leather industry $[18,19]$. However, due to (i) the poor enforcement of the environmental protection laws in the country, (ii) lack of awareness by the manufacturers, and (iii) the unavailability of feasible and cost-effective waste treatment technology, the tanneries in the country, particularly in Modjo, have no proper wastewater treatment system before discharging into the nearby Modjo River. This, in turn, will impose a major chromium load on the receiving water body of which the water serves several other purposes downstream (i.e., domestic, irrigation, bathing, and recreational use) [20].
Several studies have reported pollution resulting from tanneries to the surrounding [1,21-23]. A study done on chromium contamination at tannery surroundings in Southeast Ethiopia found out that the soil, water, and vegetable samples from the area contain $\mathrm{Cr}$ (III) and $\mathrm{Cr}$ (VI) higher than the recommended guideline. Similarly, a study in Pakistan also revealed that most of the vegetables grown in tannery surroundings contain chromium concentration which crosses the limit set by WHO/FAO [5, 24]. Even though much work has been done, the spatial distribution of chromium pollution from tanneries to the surrounding water and soil to predict the safe distance from the source is not well studied. Besides, the amount and rate of chromium uptake among different edible plants are not well investigated in a way to determine which type of plants is safer to consume. More importantly, the speciation of chromium as it travels in the surrounding soil and water and in the edible plants to know the possible conversion and toxicity level of the chromium is not well documented. Therefore, this study aims to investigate the distribution of chromium in the soil, water, and edible plants from tannery sources in Modjo city, Ethiopia, where more than seven tanneries are located. The study also anticipated investigating the species of chromium from the source to the soil, water, and edible plants and against the distance from the source. Moreover, the study will investigate the rate of uptake of chromium from the environment by different types of plants to ascertain the safer edible plants for human consumption.

\section{Materials and Methods}

2.1. Description of the Study Area. This study was conducted in the surrounding of a city called Modjo, central Ethiopia, alongside the discharge of Colba tannery, one of the tanneries in the city. Modjo is located $70 \mathrm{~km}$ south of Ethiopia's capital, Addis Ababa, at latitude and longitude of $8^{\circ} 39^{\prime} \mathrm{N}$ $39^{\circ} 5^{\prime} \mathrm{E}$, respectively, with an elevation between 1788 and 1825 meters above sea level. The city is home to different types of old and newly established industries. The major manufacturing industries in the area are tanneries, textiles, edible oil factories, meat processing and packing industries, metal industries, and wood processing industries of which tanneries are the dominant ones. Due to this, the city is commonly called 'leather city'. Colba tannery is one of the city's tanneries located at the side of the city near Modjo River. It is a private limited company established in January 2002 , with a processing capacity of about 10,000 pieces of sheep and goatskins and 600 pieces of cowhides per day, and produces crust and finished leather to local the global markets $[25,26]$. The required samples of wastewater, river water, soil, and edible vegetables were collected inside and near the tannery while control samples were collected about $90 \mathrm{~km}$ from the study area in Zeway, assuming that the area is far away to be impacted by the tannery's discharge. The sampling stations are indicated in Figure 1.

\subsection{Sample Collection}

Water Sampling. 12 wastewater samples, four within the wastewater treatment line and 8 along the course of Modjo 

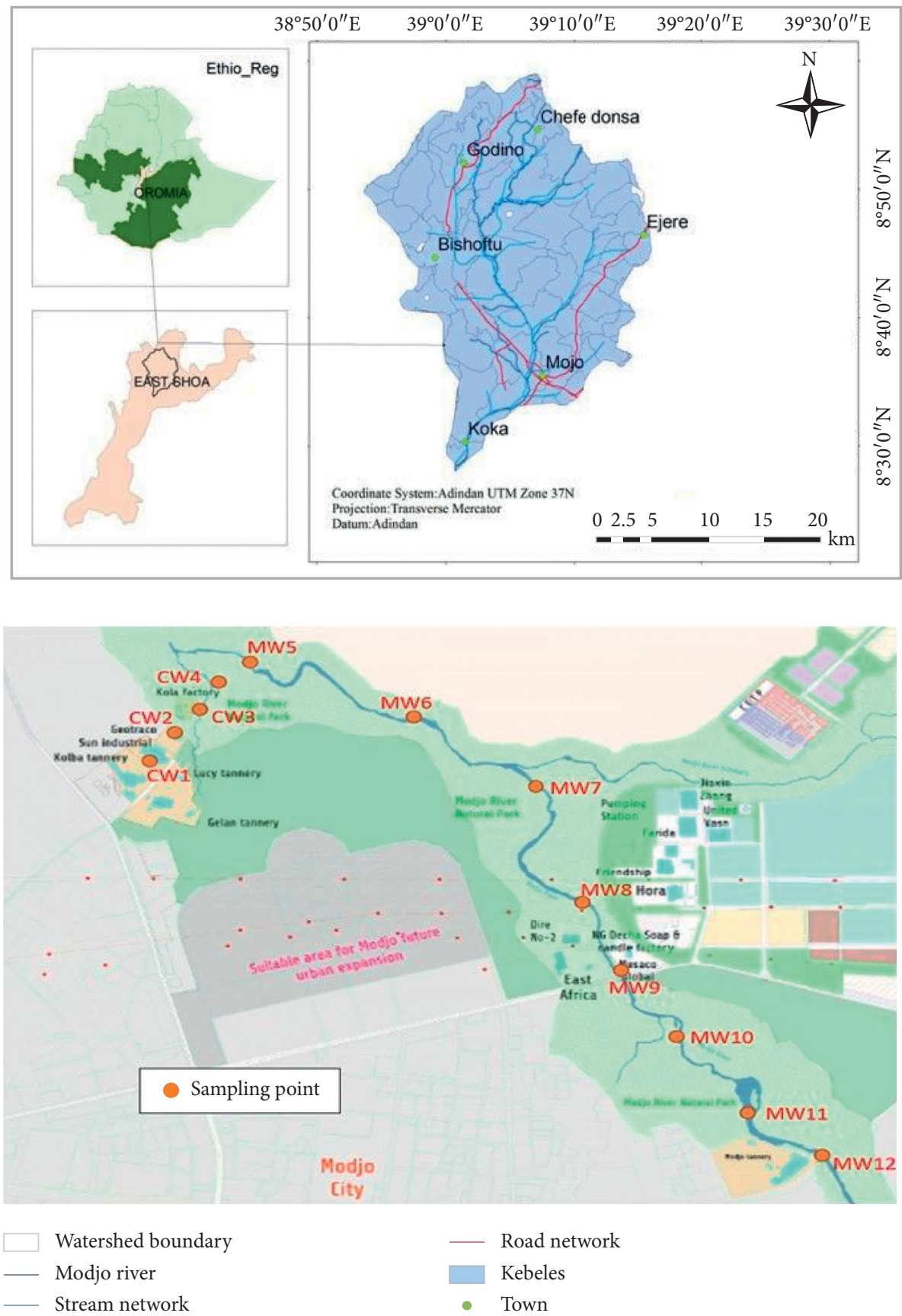

Figure 1: Location of the study area, Modjo, Ethiopia (CW=Colba tannery wastewater; $\mathrm{MW}=$ Modjo River water) (Source: United Nations Industrial Development Organization, 2015).

River, starting from the discharge point of Colba tannery were collected. Wastewater samples from the treatment plant within the tannery were collected: at discharge point from the tannery exhaust, influent of the treatment plant, (CW1), at the effluent of the primary sedimentation (CW2), at the effluent of sulfide oxidation tank (CW3), and from the final effluent after chemical precipitation (CW4). Similarly, eight water samples (MW5-MW12) were collected from Modjo River, $100 \mathrm{~m}$ apart within each sampling station starting at $10 \mathrm{~m}$ from the discharge point (MW5). Each water sample was collected at the center of the width of the river approximately at $20 \mathrm{~cm}$ depth below the surface. Considering the tannery's discharge time, the wastewater samples were collected three times a day (at 6:00 AM, at 12:00 PM, and 6:00 PM) to make a time composite representative samples of $1000 \mathrm{~mL}$ using high-density polyethylene plastic bottles. Then, preserved with $2 \mathrm{~mL} \mathrm{HNO}_{3}$ and kept at a temperature below $4^{\circ} \mathrm{C}$ in a cold box, the samples were transported to the laboratory for further analysis [5, 24, 27].

Soil Sampling. Depth composite soil samples were collected from 0 to $20 \mathrm{~cm}$ (which is assumed to be reachable by the roots) of the surface of the soil at the root of edible 
vegetables [28]. The first four soil samples (CS1-4) were collected 50 meters apart starting just from the edge of the treatment plant to the river receiving the discharge, due to the closeness to the source of chromium. The next eight samples (MS1-8) were collected 100 meters apart, assuming lower concertation of chromium due to the distance from the source, and 10 meters away from the river (near points where the water samples were collected). The rest 6 samples (PS1-6) were collected from the root of the edible vegetables by gently shaking them off. The collected soil samples were then kept in a sealed polyethylene bag and transported to the laboratory within 6 hours of the collection time.

Plant (Vegetable) Sampling. Plant parts were collected from edible vegetables, which are grown at the side of the river just below the temporary disposal site for leather shavings, during their harvest time, from mid of September to mid of October. The sampling site was selected because of the proximity to Modjo River and the solid waste from the tannery, which is about $500 \mathrm{~m}$ from Colba tannery and 75-100 meters from the bank of the river. Six different edible plants, that is, lettuce (Lactuca sativa) and cabbage (Brassica oleracea) from leaf edible, beetroot (Beta vulgaris) and carrot (Daucus carota) from root edible, and tomato (Lycopersicon esculentum) and green pepper (Capsicum annuum) from fruit edibles vegetables, were purposively selected due to their large production and higher demand by the local community. To make the sample representative, $1 \mathrm{~kg}$ of a sample from each type of individual plant parts was collected from the leaf, fruit, or root of the plant $[22,29]$. A control sample was collected from the same edible plants grown about $90 \mathrm{~km}$ away from the study site.

\subsection{Sample Digestion and Preparation. Wastewater samples} were digested by adding $10 \mathrm{~mL}$ aqua regia (with a $3: 1$ ratio of $\mathrm{HCL}$ to $\mathrm{HNO}_{3}$ ) and $2 \mathrm{~mL} \mathrm{H}_{2} \mathrm{O}_{2}(30 \%)$ to $50 \mathrm{~mL}$ of the filtered samples in a $250 \mathrm{~mL}$ flask. The mixture was then digested on a behrotest ${ }^{\circledR}$ k12 Kjeldahl block digestion apparatus at a programmed temperature of $300^{\circ} \mathrm{C}$ for 2 hours until the volume of the sample reaches $10 \mathrm{~mL}$. The digested samples were then kept in a refrigerator for 12 hours for chromium content determination $[22,30]$.

The soil samples collected were first air-dried at room temperature, dirt removed manually, and ground and sieved through $0.2 \mathrm{~mm}$ mesh. The rotten and damaged parts of the dibble portion of the plant were removed, and the sample was then washed with water to remove dirt, which later was rinsed repeatedly with deionized water before being dried at $60^{\circ} \mathrm{C}$. After gaining a constant weight, the plant samples were ground in a pestle and mortar and sieved through $0.2 \mathrm{~mm}$ mesh. Finally, both the soil and plant samples were kept in a polyethylene bag for digestion [30]. Digestion of soil and plant samples was done by taking $5 \mathrm{~g}$ of air-dried and homogenized samples from each and transferring them into a $250 \mathrm{~mL}$ flask. Then, $7 \mathrm{~mL}$ of a mixture of $\mathrm{HNO}_{3}, \mathrm{HCLO}_{4}$, and $\mathrm{H}_{2} \mathrm{O}_{2}$ with a volume-to-volume ratio of $4: 2: 1$, respectively, was added to the flask whereas $6 \mathrm{~mL}$ aqua regia modified with $\mathrm{H}_{2} \mathrm{O}_{2}$ with a volume-to-volume ratio of $3: 1: 0.5$ of $\mathrm{HCL}, \mathrm{HNO}_{3}$, and $\mathrm{H}_{2} \mathrm{O}_{2}$, respectively, was added to the soil samples. All the mixtures were then subjected to digestion using Kjeldahl digestion apparatus fitted to a reflux condenser for 3 hours at $270^{\circ} \mathrm{C}$ $[31,32]$. After cooling at room temperature for 10 minutes, $15 \mathrm{~mL}$ distilled water was added to the mixtures to dilute the concentration of the acid. Then, the solutions were filtered with $100 \mathrm{~mm}$ Whatman filter paper into a $50 \mathrm{~mL}$ flask by repeatedly rinsing not to lose the chromium until the volume reaches $45 \mathrm{~mL}$ and finally filled to the mark by adding $2 \%$ $\mathrm{HNO}_{3}[5,22]$. The reference samples collected from the control area were also digested with the same method. Finally, triplicate digested samples from each category (soil and plant) were kept in a refrigerator for 12 hours for the determination of the chromium concentration.

2.4. Laboratory Determination of Chromium. The $\mathrm{pH}$ of the water samples was measured on-site using a portable $\mathrm{pH}$ meter (Hach Lange HQ40D). The total chromium and $\mathrm{Cr}$ (VI) content of the wastewater, soil, and plant samples were analyzed using UV/Vis spectrophotometer (DR 5000) and ICP-OES (ARCOS FHS12). Standard solutions of chromium were prepared from $1000 \mathrm{mg} \mathrm{L}^{-1} \mathrm{~K}_{2} \mathrm{Cr}_{2} \mathrm{O}_{7}$ stock solution by diluting to the appropriate working concentration. The UV/ Vis spectrophotometer was calibrated using five series of working standards prepared from the stock solution. A $1 \mathrm{~mL}$ 1,5-diphenylcarbazide solution was added to each sample and working standard solution. For the highest recovery of chromium, the $\mathrm{pH}$ of the sample was adjusted approximately to one. Then, the equilibrium $\mathrm{Cr}$ (VI) concentration was determined from the absorbance of the complex formed between $\mathrm{Cr}$ (VI) and 1, 5-diphenylcarbazide using a spectrophotometer at $540 \mathrm{~nm}$. After oxidizing a portion of the samples using the $\mathrm{KMnO}_{4}$ method, the total chromium (measures as $\mathrm{Cr}$ (VI) from the oxidized samples) in the samples was measured following the EPA 3060A method. Finally, the concentration of $\mathrm{Cr}$ (III) in the soil samples was calculated from the difference between the two [33-35].

2.5. Statistical Analysis. The significance of the difference of chromium concentration between different types of plants was tested using Friedman rank tests $\left(\mathrm{X}^{2}\right.$ and $p$ value) while the difference of the chromium concentration along the course of the river for both the water and soil samples was tested by Kendall's tau-b test ( $r$ ) using SPPS 20 (IBM, USA). In Kendall's tau-b, test, values vary from -1 to 1 in which an increase from zero in both directions shows a significant difference between data points while the negative or positive sign shows the direction of increase or decrease along with the data points. The Friedman test compares the mean ranks between the related groups and indicates how the groups differed. A Friedman test is significant when the $p$ value is less than 0.05 for a specific degree of freedom and chi-square value.

\section{Results and Discussion}

3.1. Chromium in Water. Colba tannery, like most other tanneries in Ethiopia and elsewhere, uses basic chromium 
sulfate as a tanning agent. The chromium concentration and specification in the Colba tannery wastewater treatment plant are shown in Table 1. The total chromium measured at the entrance of the treatment plant is almost similar to the $\mathrm{Cr}$ (III) concentration with only a very small concentration of $\mathrm{Cr}$ (VI), which later slightly increases through the line in the treatment plant. At the final stage of the treatment, in the effluent discharged to the nearby river (Modjo River), the total chromium is reduced from $2379.55 \pm 0.12 \mathrm{mg} \mathrm{L}^{-1}$ to $753.402 \pm 0.22 \mathrm{mg} \mathrm{L}^{-1}$ indicating the poor performance of the treatment plant. Despite the reduction in the concentration of $\mathrm{Cr}$ (III) and total chromium at each sampling site, the concentration of $\mathrm{Cr}(\mathrm{VI})$ continuously increases toward the effluent side. The detection of $\mathrm{Cr}(\mathrm{VI})$ at a concentration from $0.12 \pm 0.014 \mathrm{mg} \mathrm{L}^{-1}$ to $0.322 \pm 0.07 \mathrm{mg} \mathrm{L}^{-1}$ in the wastewater treatment plant, bearing in mind the fact that $\mathrm{Cr}$ (III) is the only tanning agent used by the tannery, indicates the oxidation of $\mathrm{Cr}$ (III) to $\mathrm{Cr}$ (VI) due to the presence of precursors. More increment in Cr (VI) concentration was observed after the sulfide oxidation tank, which might be due to the high dissolved oxygen, and enzymes and fats from the waste stream from other parts of the tanning process which may facilitate the possible oxidation of $\mathrm{Cr}$ (III) to $\mathrm{Cr}$ (VI) $[15,16]$. Moreover, the longer retention time and acidity of the medium facilitate the possible oxidation of chromium to $\mathrm{Cr}$ (VI) $[36,37]$. As evidenced by Asfaw et al., $\mathrm{Cr}$ (VI) is more stable and exists at a higher proportion in acidic mediums as $\mathrm{HCrO}_{4}^{-}(1<\mathrm{pH}<7)$ which is the case of this study [22].

The chromium concentration in the river just below the discharge point of the effluent of Colba tannery is shown in Figure 2. As expected, due to the effects of dilution, adsorption, and other surface water phenomenon, Cr (III) and total chromium concentrations significantly descend downstream at each sampling station from MW5 to MW12 $(r=-0.93, p<0.05)$. However, Cr (VI) concentration in the river increased on the downstream side in the first four stations and decreased in the two consecutive sites downstream until it becomes not detectable in the last two stations. Understandably, exposure to the outer environment creates favorable conditions for the oxidation of $\mathrm{Cr}$ (III) to $\mathrm{Cr}$ (VI). Though the dilution and adsorption reduce the measured total chromium downstream the course of the river, the $\mathrm{Cr}(\mathrm{VI})$ concentration increases from $1.23 \pm 0.032 \mathrm{mg} \mathrm{L}^{-1}$ to $2.82 \pm 0.02 \mathrm{mg} \mathrm{L}^{-1}$, which is far above the guideline value by the WHO for humans health and animals [8]. The cumulative trend of $\mathrm{Cr}(\mathrm{VI})$ as the river flows downstream seems to decrease which is not statistically significant $(r=-0.76, p>0.05)$. Then, at 600 and 800 meters from the discharge point, the concentration of $\mathrm{Cr}$ (VI) becomes nondetectable using both UV/Vis and ICP-OES, which may be mainly due to the dilution and adsorption effect in the bottom sediment as the distance increases downstream $[37,38]$.

3.2. Chromium in Soil. The first four soil samples were collected 50 meters apart starting from the final effluent
TABLE 1: Concentration and species of chromium in the wastewater treatment plant of Colba tannery $(\mathrm{CW}=$ Colba tannery water sample) $[n=3]$.

\begin{tabular}{lccc}
\hline $\begin{array}{l}\text { Water } \\
\text { sample }\end{array}$ & $\mathrm{Cr}(\mathrm{III})\left(\mathrm{mg} L^{-1}\right)$ & $\begin{array}{c}\mathrm{Cr}(\mathrm{VI}) \\
\left(\mathrm{mgL} L^{-1}\right)\end{array}$ & $\operatorname{Total~} \mathrm{Cr}\left(\mathrm{mgL} L^{-1}\right)$ \\
\hline CW1 & $2379.43 \pm 0.088$ & $0.12 \pm 0.014$ & $2379.55 \pm 0.12$ \\
CW2 & $2190.08 \pm 1.081$ & $0.162 \pm 0.07$ & $2190.242 \pm 1.106$ \\
CW3 & $811.84 \pm 0.47$ & $0.207 \pm 0.045$ & $812.047 \pm 0.49$ \\
CW4 & $811.84 \pm 0.20$ & $0.322 \pm 0.07$ & $753.402 \pm 0.22$ \\
\hline
\end{tabular}

outlet toward the River to ascertain the chromium contamination level and the possible oxidation and reduction in the direction toward the river. As indicated in Table 2, both $\mathrm{Cr}$ (III) and total chromium decreased downstream toward the discharge point from $1811.4 \pm 0.21$ to $791.5 \pm 0.17 \mathrm{mg} \mathrm{kg}^{-1}$ and from $1812.21 \pm 2.21$ to $792.47 \pm 1.04 \mathrm{mg} \mathrm{kg}^{-1}$, respectively. As it gets distant from the outlet of effluent, the chance of interaction of the chromium with different organic and inorganic constituents of the soil also increases. This, in turn, facilitates the oxidation or reduction of chromium from one form to the other, adsorption on porous media in the soil, uptake by plants, and percolation to the depth of the ground thereby reducing the concentration of $\mathrm{Cr}$ (III) and total chromium in the downside of the sampling stations $[39,40]$. On the contrary, the rise of $\mathrm{Cr}$ (VI) concentration in the downside sampling stations is mainly due to the increased possibility of exposure to the environment, which serves as precursors for oxidation of $\mathrm{Cr}$ (III) to $\mathrm{Cr}$ (VI) [41, 42]. The chromium concentration of each species from the tannery surrounding is significantly higher than the control sample $(p<0.05)$.

The soil samples collected at the riverbank, paired with the water samples from Modjo River, reveal the distribution of chromium species as the distance from the source and the possible change of the chromium forms within the distance. As shown in Figures 3(a) and 3(b), the overall trend of chromium content in the soil decreased as the site gets distant from the source. This is expected due to the interaction of the chromium with different environmental compartments which resulted in adsorption to the soil or uptake by plants [42]. The Cr (VI) concentration, however, slightly increases in the first four sites, which later became inconsistent to the end. Looking to the overall $\mathrm{Cr}(\mathrm{VI})$ concentration, it exhibited that there is a slightly significant increase downstream along the course of the sampling stations $(r=0.3 ; p<0.05)$ while the total chromium and Cr (III) concentration significantly reduced downstream within the sites $(r=-0.6 ; p<0.05)$. The lowest $\mathrm{Cr}$ (III) and $\mathrm{Cr}$ (VI) concentration measured in the soil is $2.78 \pm 0.37$ and $4.57 \pm 1.01 \mathrm{mg} \mathrm{kg}^{-1}$, respectively, which is higher than $(p<0.05)$ the control and the guideline value of chromium in environmental samples [42]. Similarly, a study by Homa et al. found out that the concentration of $\mathrm{Cr}$ (III) and total chromium decreases as the distance from the tannery treatment plant increases. However, the Cr (VI) concentration decreases downside while, in this study, the $\mathrm{Cr}$ (VI) concentration, on the contrary, is higher downstream except for the very furthest points [5]. The discrepancy in the results may be because of higher $\mathrm{pH}$ which facilitates the 


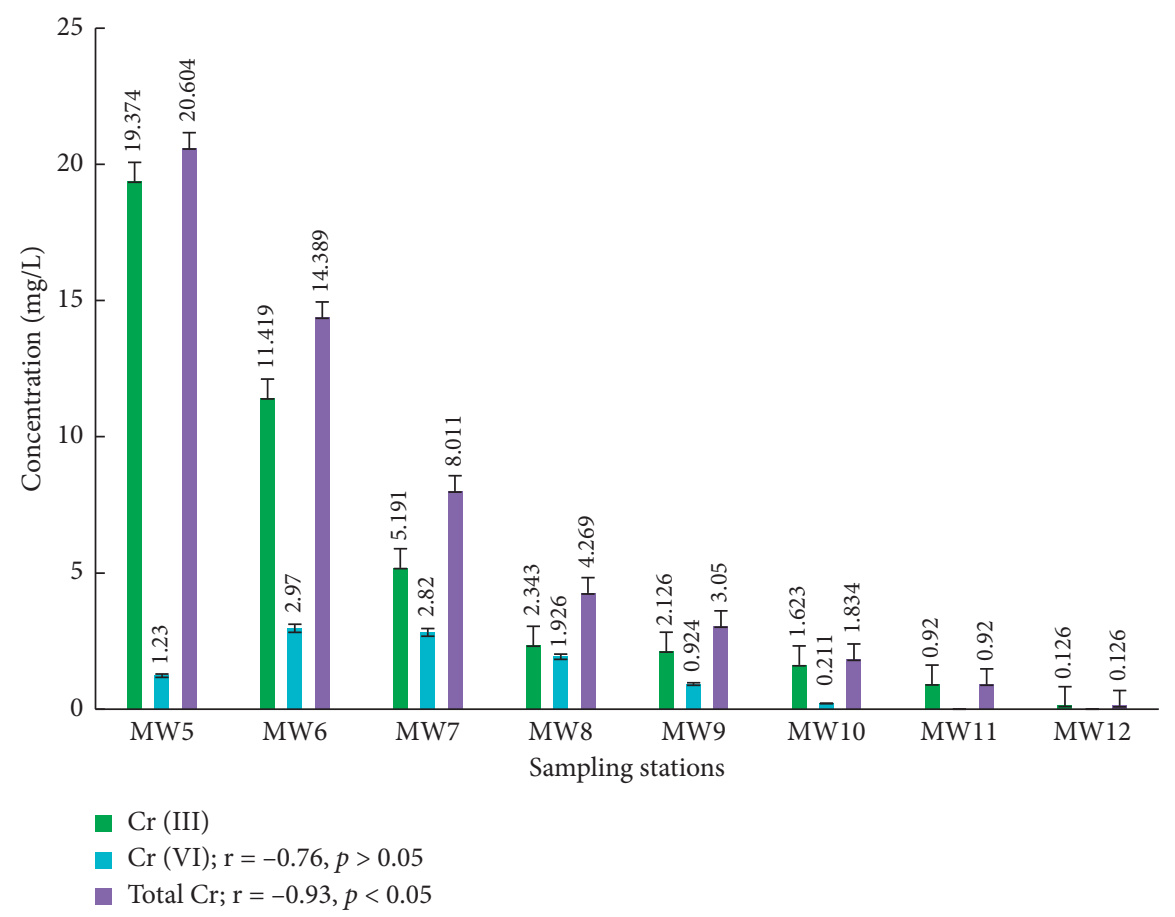

Figure 2: Concentration and species of chromium at Modjo River below the discharge point of Colba tannery, Modjo, Ethiopia (MW = Modjo River water sample).

TABLE 2: Concentration and species of chromium in soil between the wastewater treatment plant of Colba tannery and the receiving river (CS=Colba tannery soil sample) [mean $\left.\pm \mathrm{SD} \mathrm{mg} \mathrm{kg}^{-1}, n=3\right]$.

\begin{tabular}{lccccc}
\hline Soil sample & Cr (III) & Water-soluble Cr (VI) & Cr (VI) & Total Cr (UV/vis) & Total Cr (ICP-OES) \\
\hline CS1 & $1811.4 \pm 0.21$ & $0.183 \pm 0.02$ & $0.621 \pm 0.02$ & $1812.21 \pm 2.21$ & $1809.33 \pm 0.31$ \\
CS2 & $1525.7 \pm 0.32$ & $0.221 \pm 0.01$ & $0.783 \pm 0.01$ & $1526.48 \pm 3.32$ & $1525.71 \pm 1.42$ \\
CS3 & $1193.6 \pm 0.41$ & $0.331 \pm 0.32$ & $0.915 \pm 0.32$ & $1194.51 \pm 3.32$ & $1196.02 \pm 0.67$ \\
CS4 & $791.5 \pm 0.17$ & $0.362 \pm 0.04$ & $0.973 \pm 0.04$ & $792.47 \pm 1.04$ & $792.33 \pm 0.44$ \\
Control & $0.18 \pm 0.03$ & ND & ND & $0.18 \pm 0.03$ & $0.07 \pm 0.01$ \\
\hline
\end{tabular}

ND: not detected.

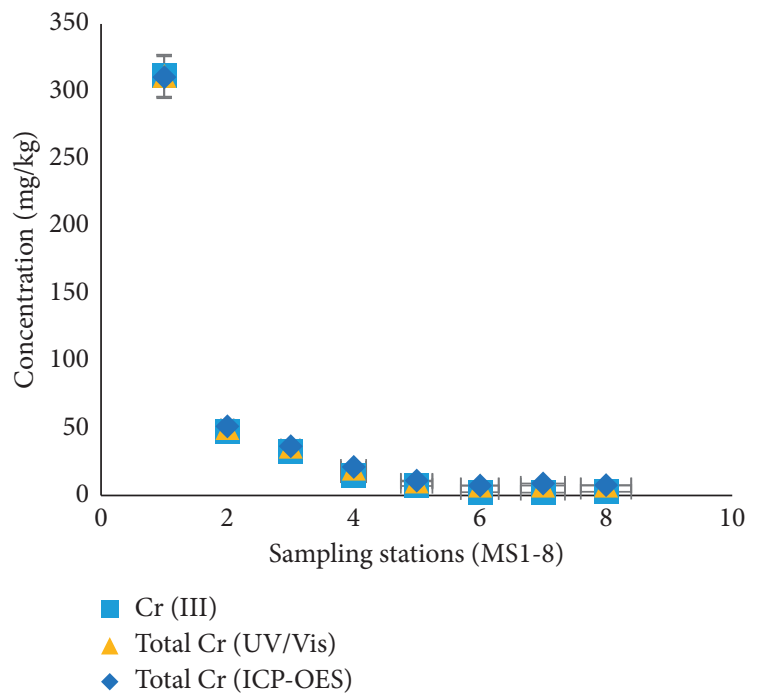

(a)

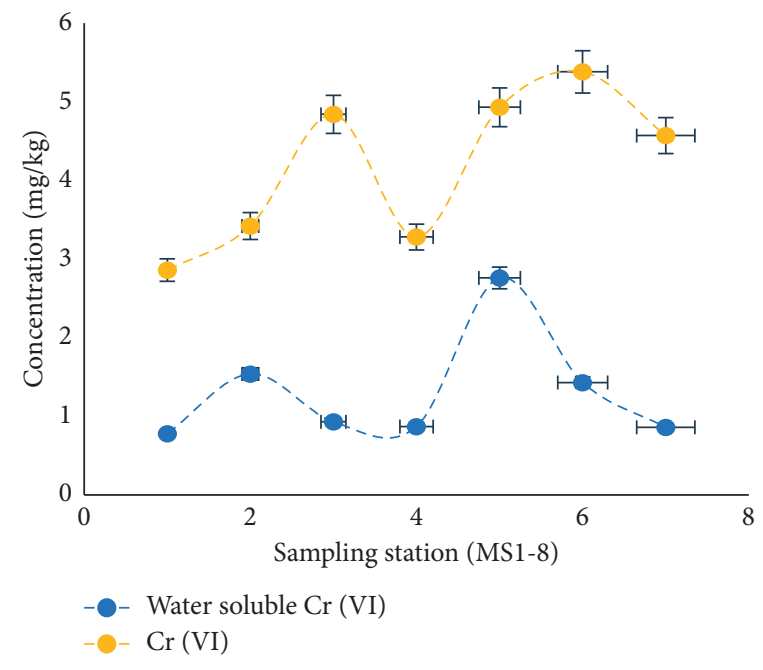

(b)

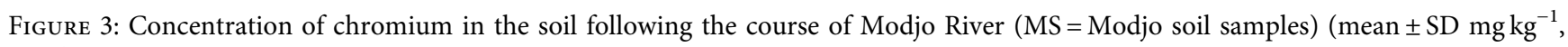
$n=3)$. 
TAвLE 3: Chromium concentration in edible plants grown in the tannery surroundings $\left[\mathrm{mg} \mathrm{kg}^{-1} \operatorname{mean} \pm \mathrm{SD}, n=3\right]$.

\begin{tabular}{lccccccc}
\hline \multirow{2}{*}{ Vegetable type } & \multicolumn{2}{c}{ Cr (III) } & \multicolumn{2}{c}{ Cr (VI) } & \multicolumn{2}{c}{ Total Cr } & \multirow{2}{*}{ Total Cr (Control) } \\
& Soil & Plant & Soil & Plant & Soil & Plant \\
\hline Lettuce & $862.54 \pm 5.91$ & $11.75 \pm 0.73$ & $2.33 \pm 1.21$ & $0.051 \pm 0.01$ & $864.87 \pm 5.22$ & $11.80 \pm 0.53$ & $0.14 \pm 0.01$ \\
Cabbage & $874.41 \pm 7.35$ & $9.21 \pm 0.44$ & $1.97 \pm 0.62$ & $0.042 \pm 0.01$ & $876.38 \pm 7.33$ & $9.25 \pm 0.71$ & $0.26 \pm 0.01$ \\
Tomato & $866.52 \pm 2.77$ & $8.18 \pm 0.17$ & $2.77 \pm 1.27$ & $0.035 \pm 0.02$ & $869.29 \pm 2.72$ & $8.22 \pm 0.16$ & $0.31 \pm 0.01$ \\
G. pepper & $864.23 \pm 9.51$ & $7.94 \pm 0.19$ & $2.84 \pm 0.41$ & $0.041 \pm 0.01$ & $867.07 \pm 9.53$ & $7.98 \pm 0.63$ & $0.18 \pm 0.01$ \\
Beetroot & $881.53 \pm 4.81$ & $12.88 \pm 0.86$ & $2.61 \pm 0.88$ & $0.066 \pm 0.02$ & $884.14 \pm 4.82$ & $12.95 \pm 0.61$ & $0.21 \pm 0.01$ \\
Carrot & $887.36 \pm 7.12$ & $14.37 \pm 1.23$ & $2.13 \pm 1.03$ & $0.078 \pm 0.02$ & $889.49 \pm 7.12$ & $14.45 \pm 0.34$ & $0.12 \pm 0.01$ \\
\hline
\end{tabular}

TABLE 4: Chromium concentration in edible parts of plants from tannery-contaminated area $\left[\mathrm{mg} \mathrm{kg}^{-1} \mathrm{mean} \pm \mathrm{SD}, n=3\right]$.

\begin{tabular}{lcccc}
\hline Vegetable type & Total Cr & Cr (III) & Cr (VI) & Total Cr (control) \\
\hline Lettuce & 11.8 & 11.75 & 0.051 & 0.14 \\
Cabbage & 9.25 & 9.21 & 0.042 & 0.26 \\
Tomato & 8.22 & 8.18 & 0.035 & 0.31 \\
Green pepper & 7.98 & 7.94 & 0.041 & 0.18 \\
Beetroot & 12.95 & 12.88 & 0.066 & 0.21 \\
Carrot & 14.45 & 14.37 & 0.078 & 0.12 \\
\hline
\end{tabular}

reduction of $\mathrm{Cr}$ (VI) into $\mathrm{Cr}$ (III) and the clay soil formation which may adsorb the $\mathrm{Cr}(\mathrm{VI})$, unlike the conditions in this study $[22,40]$. The increase in the $\mathrm{Cr}(\mathrm{VI})$ concentration in this study is also supported by other studies such as Chattopadhyay et al., Walsh and O'Halloran, and Herschy. The findings of these studies show that soil samples that did not have a detectable concentration of $\mathrm{Cr}(\mathrm{VI})$ at the beginning of the study happen to have a significant concentration after exposure to environmental factors that facilitate the oxidation of the available $\mathrm{Cr}$ (III) from tannery discharges years later $[8,39,43]$. However, in the control samples collected far from the industrial zone, there was no detectable concentration of $\mathrm{Cr}(\mathrm{VI})$ by both UV/Vis and ICP-OES measurement, which confirms that the possible source of chromium in the surrounding soil is possibly the tannery discharge.

3.3. Chromium in Edible Plants. There are various studies, which indicate the potential of plants to accumulate chromium and other metals and later consumed by humans and animals [22-24, 44, 45].

As depicted in Table 3, 0.9 to $1.6 \%$ of the Cr (III) and 1.2 to $3.6 \%$ of the $\mathrm{Cr}$ (VI) measured in the soil collected from the root of each plant were found in the edible parts. The concentrations of $\mathrm{Cr}$ (III) and total chromium in the soil of the cultivation area were from $862.54 \pm 5.91$ to $887.36 \pm 7.12 \mathrm{mg} \mathrm{kg}^{-1}$ and $864.87 \pm 5.22$ to $889.49 \pm 7.12 \mathrm{mg} \mathrm{kg}^{-1}$, respectively, while the total chromium concentration of the control area was only $0.18 \pm 0.01 \mathrm{mg} \mathrm{kg}^{-1}$. Similarly, the total chromium concentration measured in the edible part of the plants from the tannery surrounding was from $7.98 \pm 0.63 \mathrm{mg} \mathrm{kg}^{-1}$ for green pepper to $14.45 \pm 0.34 \mathrm{mg} \mathrm{kg}^{-1}$ for carrot. This is significantly higher $(p<0.05)$ than the total chromium measured in plants from the control area, which is between $0.14 \mathrm{mg} \mathrm{kg}^{-1}$ for lettuce and $0.31 \pm 0.01 \mathrm{mg} \mathrm{kg}^{-1}$ for tomato.

Chromium concentrations measured in the edible plants from the tannery surrounding are not all the same in all plant types studied. Green pepper $\left(0.041,7.94\right.$, and $7.98 \mathrm{mg} \mathrm{kg}^{-1}$, respectively) and tomato $\left(0.035,8.18\right.$, and $8.22 \mathrm{mg} \mathrm{kg}^{-1}$, respectively) have the lowest $\mathrm{Cr}$ (VI), $\mathrm{Cr}$ (III), and total chromium concentration from the six plant types studied. As presented in Table 4, the highest $\mathrm{Cr}$ (VI), $\mathrm{Cr}$ (III), and total chromium were recorded for carrot $\left(0.078,14.37\right.$, and $14.45 \mathrm{mg} \mathrm{kg}^{-1}$, respectively) and beetroot $\left(0.066,12.88\right.$, and $12.95 \mathrm{mg} \mathrm{kg}^{-1}$, respectively). The overall pattern of chromium concentration trend is carrot $>$ beetroot $>$ lettuce $>$ cabbage $>$ tomato $>$ green pepper. It is revealed that the root part of plants accumulates more chromium than the leaf, and the fruit part accumulates the lowest. These findings are comparable with similar studies elsewhere which also indicates that roots are the highest accumulators while leaves are lower and fruits are the lowest $[5,27,46]$.

As illustrated in Figures 4(a) and 4(b), the highest concentration of chromium found in carrot and beetroot confirms that roots are part of the plants that accumulate more than the upper parts of the plant [5]. Huffman and Allaway (1973) found out that the chromium concentrations in the root and the seeds were 98 and $0.1 \%$, respectively, while a study by Gopal et al. (2009) also found 10 times more chromium accumulated in roots than the leaves of the dame plant $[47,48]$. This indicates that curiosity is highly important in choosing what type of plant to harvest and eat in contaminated areas and which part of the plant to consume.

There is very little known about chromium uptake and occurrence by plants so far. From what is known, the chromium uptake mechanism does not have a specific route and it is more dependent on the species of chromium to be absorbed $[49,50]$. The soil on which plants are grown contains elements and nutrients other than chromium which may impose competition for carriers between the $\mathrm{Cr}$ (VI) and other soil constituents like iron, sulfur, and phosphorus. However, Cr (VI) uptake is an active mechanism accomplished by carriers which are useful for the uptake of necessary plant nutrients [33].

The high concentration of $\mathrm{Cr}(\mathrm{VI})$ in this study suggests that water-soluble $\mathrm{Cr}$ (VI) can readily be taken up by plants 


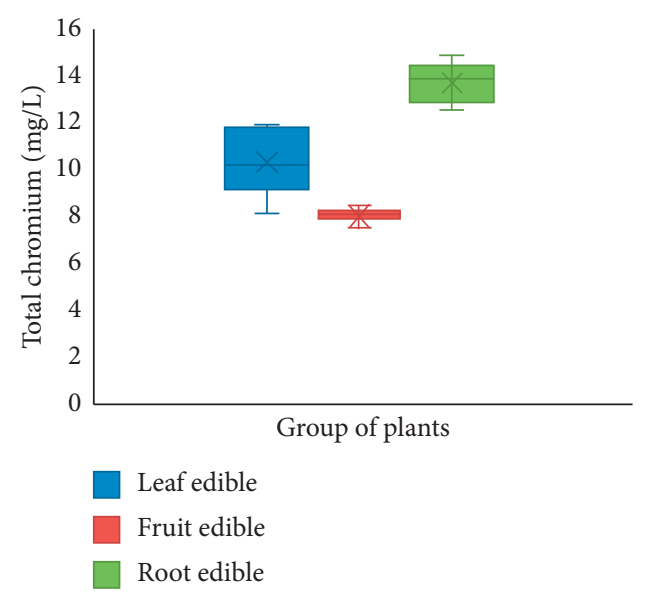

(a)

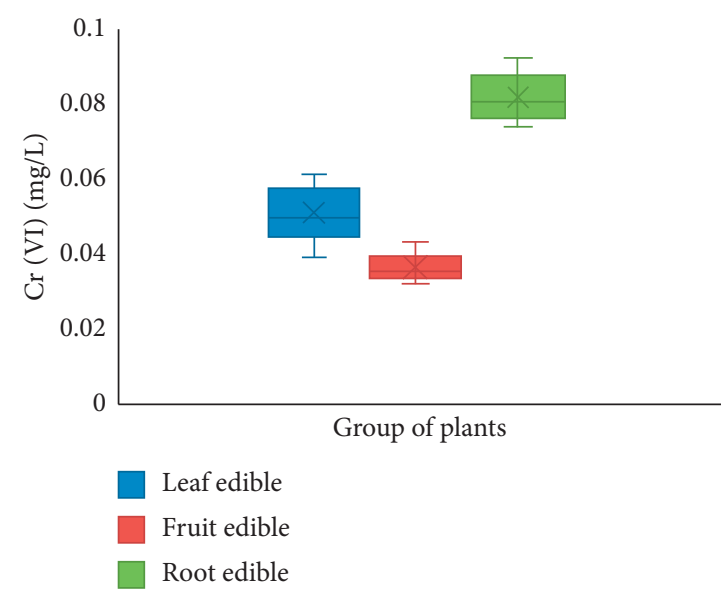

(b)

FIgURE 4: Boxplot showing the variability of chromium concentration among plant types ((a) total chromium; (b) Cr (VI)).

while there are still studies that suggest $\mathrm{Cr}(\mathrm{VI})$ will be reduced to $\mathrm{Cr}$ (III) during uptake [51]. Cr (VI), contrary to $\mathrm{Cr}$ (III), is highly mobile due to its solubility thereby being more toxic even at lower concentrations. In the noncontaminated area, normal $\mathrm{Cr}$ (VI) concentration is usually less than $1 \mathrm{mg} \mathrm{kg}^{-1}$ and it is toxic to plants when it is 0.5 to $5 \mathrm{mg} \mathrm{kg}^{-1}$ and more in plant nutrient solutions based on the tolerating capacity of the specific plant. It is also wise to notice that the $\mathrm{Cr}$ (VI) concentration in the edible plants is higher than the permissible limit in which the cumulative effect will be a serious health risk in lifetime exposure $[33,52]$.

\section{Conclusion}

In conclusion, the study confirmed that total chromium, $\mathrm{Cr}$ (III), and $\mathrm{Cr}$ (VI) concentrations are significantly higher in areas contaminated with tannery waste in comparison to noncontaminated areas. Chromium concentration in water and soil samples exhibited a significant reduction as the distance from the source increases. However, detection of $\mathrm{Cr}$ (VI) downstream than the upstream sites indicates that using Cr (III) for manufacturing is not a guarantee to avoid toxic $\mathrm{Cr}$ (VI) as long as oxidation in the environment is possible. It is also concluded that edible plants accumulate a substantial amount of chromium in their parts and the concentration of chromium accumulated is dictated by the type and part of the plant. Roots of plants accumulate more chromium than the leaf and the fruit. Therefore, the establishment of appropriate industrial wastewater treatment systems feasible for developing countries, implementation of local and international environmental regulations, public awareness on selection, and use of edible plants grown in contaminated areas are recommended to reduce the current high contamination of chromium in the environment and its health impact in tannery surrounding area.

\section{Data Availability}

All the data that support the findings of this study are included within this article.

\section{Conflicts of Interest}

The authors declare that they have no conflicts of interest.

\section{Acknowledgments}

The authors would like to acknowledge Jimma University (JU), Ethiopia, for partially funding this work as part of a Ph.D. project and Horticoop, Ethiopia (Agriculture) PLC, for the analyses of some of the samples.

\section{References}

[1] A. Ertani, A. Mietto, M. Borin, and S. Nardi, "Chromium in agricultural soils and crops: a review," Water, Air, \& Soil Pollution, vol. 228, 2017.

[2] F. L. da Silva, G. L. Scheel, M. G. Segatelli, and C. R. T. Tarley, "7-redox preconcentration/speciation of chromium by using nanocomposites based on carbon nanotubes and functional polymers," in Micro and Nano Technologies, pp. 139-180, Elsevier, Amsterdam, Netherlands, 2018.

[3] H. Oliveira, "Chromium as an environmental pollutant: insights on induced plant toxicity," Journal of Botany, vol. 2012, Article ID 375843, 8 pages, 2012.

[4] A. D. Covington, Tanning Chemistry: The Science of Leather, Royal Society of Chemistry, London, UK, 2009, https://books. google.com.et/books?id=Og7OwDQp0CwC.

[5] D. Homa, E. Haile, and A. P. Washe, "Determination of spatial chromium contamination of the environment around industrial zones," International Journal of Analytical Chemistry, vol. 2016, Article ID 7214932, 7 pages, 2016.

[6] J. Guertin, J. A. Jacobs, and C. P. Avakian, Chromium(VI) Handbook, CRC Press, Baco Rotan, FL, USA, 2016.

[7] B. Kakavandi, R. R. Kalantary, M. Farzadkia et al., "Enhanced chromium (VI) removal using activated carbon modified by zero valent iron and silver bimetallic nanoparticles," Journal of Environmental Health Science \& Engineering, vol. 12, 2014.

[8] R. W. Herschy, "Water quality for drinking: WHO guidelines," in Encyclopedia of Hydrology and Lakes, pp. 706-712, Springer, Dordrecht, Netherlands, 2012.

[9] L. Khezami and R. Capart, "Removal of chromium(VI) from aqueous solution by activated carbons: kinetic and 
equilibrium studies," Journal of Hazardous Materials, vol. 123, no. 1-3, pp. 223-231, 2005.

[10] A. Molik, J. Siepak, R. Świetlik, and J. R. Dojlido, "Identification of chromium species in tanning solutions," Polish Journal of Environmental Studies, vol. 13, pp. 311-314, 2004.

[11] M. Mwinyihija, A. Meharg, J. Dawson, N. J. C. Strachan, and K. Killham, "An ecotoxicological approach to assessing the impact of tanning industry effluent on river health," Archives of Environmental Contamination and Toxicology, vol. 50, no. 3, pp. 316-324, 2006.

[12] R. Aravindhan, B. Madhan, J. R. Rao, B. U. Nair, and T. Ramasami, "Bioaccumulation of chromium from tannery wastewater: an approach for chrome recovery and reuse," Environmental Science \& Technology, vol. 38, no. 1, pp. 300306, 2004.

[13] S. Cao, K. Wang, S. Zhou et al., "Mechanism and effect of high-basicity chromium agent acting on Cr-WastewaterReuse system of leather industry," ACS Sustainable Chemistry \& Engineering, vol. 6, no. 3, pp. 3957-3963, 2018.

[14] E. Mengistie, I. Smets, and T. Van Gerven, "Ultrasound assisted chrome tanning: towards a clean leather production technology," Ultrasonics Sonochemistry, vol. 32, pp. 204-212, 2016.

[15] S. Avudainayagam, M. Megharaj, G. Owens, R. S. Kookana, D. Chittleborough, and R. Naidu, "Chemistry of chromium in soils with emphasis on tannery waste sites," Reviews of Environmental Contamination and Toxicology, vol. 178, pp. 53-91, 2003.

[16] Y. Tang, S. M. Webb, E. R. Estes, and C. M. Hansel, "Chromium(iii) oxidation by biogenic manganese oxides with varying structural ripening," Environ. Sci.: Processes Impacts, vol. 16, no. 9, pp. 2127-2136, 2014.

[17] Y.-p. Liao, Z.-x. Wang, Z.-h. Yang, L.-y. Chai, J.-q. Chen, and P.-f. Yuan, "Migration and transfer of chromium in soilvegetable system and associated health risks in vicinity of ferro-alloy manufactory," Transactions of Nonferrous Metals Society of China, vol. 21, no. 11, pp. 2520-2527, 2011.

[18] CoMESA, Study on the Competitiveness of Ethiopian Firms for Participating in CoMESA Free Trade, (2012).

[19] CSA, Agricultural sample survey, report on livestock and livestock characteristics, (2011).

[20] E. Mengistie, A. Ambelu, T. Van Gerven, and I. Smets, "Impact of tannery effluent on the self-purification capacity and biodiversity level of a river," Bulletin of Environmental Contamination and Toxicology, vol. 96, no. 3, pp. 369-375, 2016.

[21] M. L. Akele, P. Kelderman, C. W. Koning, and K. Irvine, "Trace metal distributions in the sediments of the little akaki river, Addis Ababa, Ethiopia," Environmental Monitoring and Assessment, vol. 188, no. 7, p. 389, 2016.

[22] T. B. Asfaw, T. M. Tadesse, and A. M. Ewnetie, "Determination of total chromium and chromium species in kombolcha tannery wastewater, surrounding soil, and lettuce plant samples, south wollo, Ethiopia," Advances in Chemistry, vol. 2017, Article ID 6191050, 7 pages, 2017.

[23] C. Y. Chang, H. Y. Yu, J. J. Chen, F. B. Li, H. H. Zhang, and C. P. Liu, "Accumulation of heavy metals in leaf vegetables from agricultural soils and associated potential health risks in the Pearl River Delta, South China," Environmental Monitoring and Assessment, vol. 186, no. 3, pp. 1547-1560, 2014.

[24] A. Latif, M. Bilal, W. Asghar et al., "Heavy metal accumulation in vegetables and assessment of their potential health risk," Journal of Environmental Analytical Chemistry, vol. 05, pp. 1-7, 2018.
[25] J. Grumiller, W. Raza, The Ethiopian leather and leather products Sector: an assessment of export potentials to europe and Austria, (2019).

[26] M. Adem, "Production of hide and skin in Ethiopia; marketing opportunities and constraints: a review paper," Cogent Food \& Agriculture, vol. 5, no. 1, Article ID 1565078, 2019.

[27] A. K. Weldemariam, "Assessment of lowest chromium bioaccumulation vegetables irrigated by Sheba Leather Industry contaminated water in Wukro, Tigray-Ethiopia," Current World Environment, vol. 15, no. 1, pp. 110-116, 2020.

[28] H. Gitet, P. A. Subramanian, D. Minilu et al., "Speciation of chromium in soils near sheba leather industry, wukro Ethiopia," Talanta, vol. 116, pp. 626-629, 2013.

[29] H. Chen, J. M. Arocena, J. Li, R. W. Thring, and J. Zhou, "Assessments of chromium (and other metals) in vegetables and potential bio-accumulations in humans living in areas affected by tannery wastes," Chemosphere, vol. 112, pp. 412419, 2014.

[30] K. K. Onchoke and S. A. Sasu, "Determination of hexavalent chromium $(\mathrm{Cr}(\mathrm{VI}))$ concentrations via ion chromatography and UV-vis spectrophotometry in samples collected from nacogdoches wastewater treatment plant, east Texas (USA)," Advances in Environmental Chemistry, vol. 2016, Article ID 3468635, 10 pages, 2016.

[31] U.S. EPA, "Method 3050B: acid digestion of sediments, sludges, and soils," in Revision 2U.S. EPA, Washington, DC, USA, 1996.

[32] M. Sadiq Butt, K. Sharif, B. Ehsan Bajwa, and A. Aziz, "Hazardous effects of sewage water on the environment," Management of Environmental Quality: An International Journal, vol. 16, no. 4, pp. 338-346, 2005.

[33] S. Mishra, V. Singh, S. Srivastava et al., "Studies on uptake of trivalent and hexavalent chromium by maize (Zea mays)," Food and Chemical Toxicology, vol. 33, no. 5, pp. 393-397, 1995.

[34] B. R. E. Wolf and S. A. Wilson, Evaluation of Extraction Methods for Hexavalent Chromium Determination in Dusts, Ashes, and Soils, pp. 1-24, U.S.G. Survey, Reston, VA, USA, 2010.

[35] A. Wiryawan, R. Retnowati, P. Burhan, and S. Syekhfani, "Method of analysis for determination of the chromium (cr) species in water samples by spectrophotometry with diphenylcarbazide," Journal of Environmental Chemical Engineering, vol. 5, no. 1, , 2018, https://jeest.ub.ac.id/index.php/jeest/ article/view/120.

[36] A. Apte, S. Verma, V. Tare, and P. Bose, "Oxidation of Cr(III) in tannery sludge to $\mathrm{Cr}(\mathrm{VI})$ : field observations and theoretical assessment," Journal of Hazardous Materials, vol. 121, no. 1-3, pp. 215-222, 2005.

[37] A. Neelam, "Determination of chromium in the tannery wastewater, korangi, karachi," International Journal of Environmental Sciences \& Natural Resources, vol. 15, 2018.

[38] A. Kuriata-Potasznik, S. Szymczyk, A. Skwierawski, K. Glińska-Lewczuk, and I. Cymes, "Heavy metal contamination in the surface layer of bottom sediments in a flowthrough lake: a case study of lake symsar in northern poland, water (switzerland)," Water, vol. 8, 2016.

[39] A. R. Walsh and J. O'Halloran, "Chromium speciation in tannery effluent-I. An assessment of techniques and the role of organic Cr(III) complexes," Water Research, vol. 30, no. 10, pp. 2393-2400, 1996.

[40] B. K. Mandal, R. Vankayala, and L. Uday Kumar, "Speciation of chromium in soil and sludge in the surrounding tannery 
region, ranipet, Tamil nadu," ISRN Toxicology, vol. 2011, Article ID 697980, 10 pages, 2011.

[41] N. Kožuh, J. Štupar, and B. Gorenc, "Reduction and oxidation processes of chromium in soils," Environmental Science \& Technology, vol. 34, pp. 112-119, 2000.

[42] J. G. Kim and J. B. Dixon, "Oxidation and fate of chromium in soils," Soil Science and Plant Nutrition, vol. 48, no. 4, pp. 483-490, 2002.

[43] B. Chattopadhyay, S. Datta, and A. Chatterjee, "The environmental impact of waste chromium of tannery agglomerates in the east Calcutta wetland ecosystem, journal- society of leather technologists and chemists," Journal of the Society of Leather Technologists and Chemists, vol. 84, pp. 94-100, 2000, https://www.tib.eu/de/suchen/id/BLSE\%3ARN076994365.

[44] L. R. Alves, A. R. Dos Reis, and P. L. Gratão, "Heavy metals in agricultural soils: from plants to our daily life," Científica, vol. 44 , no. 3 , p. 346, 2016.

[45] S. Pajević, D. Arsenov, N. Nikolić et al., "Heavy metal accumulation in vegetable species and health risk assessment in Serbia," Environmental Monitoring and Assessment, vol. 190, 2018.

[46] F. Guerra, A. R. Trevizam, T. Muraoka, N. C. Marcante, and S. G. Canniatti-Brazaca, "Heavy metals in vegetables and potential risk for human health," Scientia Agricola, vol. 69, no. 1, pp. 54-60, 2012.

[47] E. W. D. Huffman and W. H. Allaway, "Chromium in plants. Distribution in tissues, organelles, and extracts and availability of bean leaf chromium to animals," Journal of Agricultural and Food Chemistry, vol. 21, no. 6, pp. 982-986, 1973.

[48] R. Gopal, A. H. Rizvi, and N. Nautiyal, "Chromium alters iron nutrition and water relations of Spinach," Journal of Plant Nutrition, vol. 32, no. 9, pp. 1551-1559, 2009.

[49] J. López-Luna, M. C. González-Chávez, F. J. Esparza-García, and R. Rodríguez-Vázquez, "Toxicity assessment of soil amended with tannery sludge, trivalent chromium and hexavalent chromium, using wheat, oat and sorghum plants," Journal of Hazardous Materials, vol. 163, no. 2-3, pp. 829-834, 2009.

[50] A. Zayed, C. M. Lytle, J. Qian et al., "Linked references are available on JSTOR for this article: planta Chromium accumulation ", Translocation and Chemical Speciation in Vegetable Crops, vol. 206, pp. 293-299, 2020.

[51] A. Shanker, C. Cervantes, H. Lozatavera, and S. Avudainayagam, "Chromium toxicity in plants," Environment International, vol. 31, no. 5, pp. 739-753, 2005.

[52] J. J. Mortvedt and P. M. Giordano, "Response of corn to zinc and chromium in municipal wastes applied to soil," Journal of Environmental Quality, vol. 4, no. 2, pp. 170-174, 1975. 